\title{
Paul and the Faithfulness of God \\ A Review Essay (Part 1) \\ Chris Tilling
}

Editor's note: Due to the length of this review essay, it is published in two parts.

NT Wright-or "Tom" to his friends - has inspired a generation of Christian scholars, and I count myself to be one of them. Reading volumes I and II of his "Christian Origins and the Question of God"1 helped me have the confidence to become a thinking Christian, one not bound by fear that academic research would inevitably lead to the demise of "my faith"! I owe Tom, then, a great debt of gratitude, even if I have since come to disagree with some of his positions. It goes without saying that, as a result, many of us engaged in Pauline studies have waited with great anticipation for his major work on Paul. Given Tom's learning, his eloquence and rhetorical skills, his ability to synthesise large swathes of data into a coherent and plausible hypothesis, Paul and the Faithfulness of God (hereafter PFG) ${ }^{2}$ is quite a publishing event, not to mention an enormous intellectual achievement. That said, I have a number of abiding concerns and questions to pursue, so in the following I will (1) briefly overview the volume, (2) note some outstanding questions and potential problems by focusing on what I see are a clusters of critical issues, and (3) ask why these problems have surfaced, and ask what is, then, required in response?

\section{An overview of Paul and the Faithfulness of God}

PFG is divided into two books, themselves both partitioned into two parts. Part I seeks to locate Paul in "his World", and Wright, in Chapter 1, begins the entire project via an analysis of Philemon. Paul's request in this short letter, understood against both the background of another written by Pliny the Younger, and a purported intertextual allusion to the Pentateuch in Philemon 15, shows in nuce what Wright hopes to demonstrate about Paul more generally. ${ }^{3}$ Namely, he seeks to show that Paul presents a Jewish worldview which is "radically reshaped around the crucified Messiah" (21), and precisely in this way "challenges the world of ancient paganism". ${ }^{4}$

All of this requires, Wright argues, a "thick" description of Paul in his historical and theological context, and to this end Wright develops heuristic tools to achieve his goals. These focus on the notion of "worldview", a model that involves analysis of "story", "praxis",

1. Wright, N. T. (2012). The New Testament and the People of God, Christian Origins and the Question of God: Part I. London: SPCK; Wright, N. T. (1996). Jesus and the Victory of God. London: SPCK.

2. Wright, N. T. (2013). Paul and the Faithfulness of God. Minneapolis: Fortress Press.

3. I switch now from "Tom" to "Wright" as the following review is a professional exercise-not personalunlike my introductory comments.

4. Numbers in brackets refer to the page number of PFG. 
"questions", and "symbols", together with the related "basic" and "consequent" beliefs, as well as "aims" and "intentions", "worship" and "culture". This, Wright believes, facilitates analysis both of Paul's historical particularity and his theological vision. But this theology does not "float above" first century Jewish soil; it is integrated into Paul's reworked Jewish worldview. Further, given that "a 'worldview' is not what you normally look at, but what you normally look through" (28), Wright's project is profoundly hermeneutical. ${ }^{5}$

What is more, Wright claims that his approach brings alternative paradigms for reading Paul into appropriate relation. Instead of perpetuating the battles between "participatory", "salvation-historical", ${ }^{6}$ and "apocalyptic" readings, Wright offers an alternative which can synthesise, nuance and contain all of these interpretative paradigms at once. Hence, his approach, he claims, enables the reader to discuss multiple questions at the same time, theological, ethical, political, historical and so on, without marginalising key issues. So he writes:

Only when they have been brought together again in a single, initially confusing, mass can they be sorted out properly and fitted together into a more compelling, if inevitably more complex, single picture. That is, basically, what this book is about (43-44).

Philemon is used as an example to show what this larger project looks like "in a nutshell" (cf. 49), which is why I have spent more time summarising it. Along the way, Wright resists the reduction of Paul to the so-called seven "undisputed" letters, an entirely welcome assertion, even if it is delivered without significant defense. ${ }^{7}$

Given not only Wright's concern to present a "thick" description of Paul in terms of this "worldview" model, but also that "Paul's native Jewish world" sets "the theological agenda" (46), Chapters 2-5 complete Part I by offering an overview of that Jewish world in the context of its wider Greco-Roman location. Chapter 2, of considerable importance for the rest of his thesis, offers an analysis of the worldview of Paul the Pharisee. Inevitably, his analysis of "stories" and "questions" force Wright to defend three key foundations for his later exposition of Paul, all of which have been challenged in light of his previous publications, namely: i) that there is a continuous story in which second-temple Jews understood themselves to live, one "going back to Abraham, perhaps even to Adam" (113, italics suppressed). ii) that this story is one "in search of an ending" (109), which is to say that this narrative, and certainly for Pharisees, suggested at a deep level that geographical exile had developed to become a "non-geographical" exile, though one still "concrete" and

5. Wright developed this model in Wright, N. T. (2012). The New Testament and the People of God: Christian Origins and the Question of God: Part I. London: SPCK, pp.122-137, but it is now focused on understanding Paul.

6. Wright also notes that "salvation history" is hardly a good way of describing the canonical narrative, which is more of a judgment or "condemnation-history" (see, e.g., 118, 129).

7. On this, see now Campbell, D. A. (2014). Framing Paul. Grand Rapids: Eerdmans. 
"political", "interpreted theologically" (162, against Steven Bryan), and iii) that the eschaton involved not the dissolution or disappearance of the universe, but rather its transformation and redemption (against Dale Allison and Edward Adams).

The bottom line, and one of inestimable importance for his wider exegetical proposals, is that "we must assume" that Paul the apostle "had all along been aware of this larger narrative world" (126), and that this structures the apostle's worldview, and therefore his theology, at every point. It is to say that the Bible, for Paul, "was not merely a source of types, shadows, allusions" etc., but was a coherent narrative involving a continuing exile, seen especially clearly in the combination of key passages in Deuteronomy and Daniel, and their (re)use in important second-temple texts.

Chapters 3-5 continue to summarise aspects of wider Greco-Roman philosophy (chapter 3), religion and culture (chapter 4 ) and empire (chapter 5 ). Wright will circle back to tackle these matters in light of his later discussion of Paul's theology in terms of the apostle's "mindset".

This leads to Part II, and analysis of that mindset. Wright speaks of a community's "worldview" on the one hand, and an individual's "mindset" on the other. So as before, Wright's project entails asking about Paul's practices, key symbols, stories and answers to the big questions: "who are we?", "where are we?", "when are we?" and so on. Wright canvases Paul's letters for answers to these issues, thus facilitating that "thick" description of Paul. Two important claims emerge. First, "the ekklēsia and especially its unity stand at the centre of Paul's newly framed symbolic universe" (387). Crucially, the "church" is, for Paul, in this role, "loadbearing" (398) as it "take[s] the place" (398) of the symbols which supported Paul's previous worldview (405). Second, in chapter 7 Wright tries to explain how Paul's "storied worldview" is composed, a task which involves detailing the relationship between sub-plots and narratives in Paul's thinking, particularly God and creation, Israel, and then the Jesus-story.

Wright claims: "Only when we have understood Paul's worldview do we understand why his theology is what it is, and the role it plays precisely within that worldview" (55). Therefore, the previous Parts (I-II) have laid the crucial foundations for an appreciation of Paul's theology in Part III. In this third Part, Wright uses, as his framework, what he considers to be "the three main elements of second-temple Jewish 'theology', namely monotheism, election and eschatology" (610). This structures the next three chapters, which constitute the largest section of PFG.

In the first, chapter 9, Wright presents his understanding of the way Paul reaffirmed and rethought Jewish monotheism in light of Jesus and the spirit. In particular, he seeks to show both how Paul's Christology came about, as well as its nature. Most importantly, he links Paul closely to his construal of the story of Israel, and particularly the expectation of the 
return of YHWH to the temple and the related Exodus-narrative. He sees these issues as the decisive key for understanding Paul's Christology of "divine identity" (Wright liberally makes use of Richard Bauckham's phrase throughout this chapter). ${ }^{8}$ This move, he argues, makes "all kinds of other evidence ... come back into the picture to make an even larger, more comprehensive and satisfying whole" (653). In particular, it "enables us to get to the heart of what Paul and other early Christians believed about both Jesus and the spirit, and enables us more particularly to understand why and how they came to that belief" (633, italics mine). Just as Jesus saw himself embodying the return of YHWH to Zion, as Wright argued in Jesus and the Victory of God, ${ }^{9}$ so Paul resonates with this in light of the resurrection and the experience of the spirit. Hence, the nature and cause of Paul's "divine Christology" is explained. He seeks to show all of this by deliberately and programmatically engaging in "broad brushstroke" exegesis of passages of Paul's letters. He seeks to expound not isolated verses but entire sections, hence he distinguishes between a text's "referential sequence" and "poetic sequence" (921).

After another 76 pages on the question of Paul and evil ("the dark side of revised monotheism"), Wright turns, in the largest chapter of PFG (Chapter 10), to address the question of the re-working of the people of God. This is the part many will have been impatient to read, for in it Wright tackles the controversial matter of Paul's "justification" language. However, it needs to be remembered that key moves have already been made, which is to say that Wright's argument would be short-circuited if the would-be exegete reads only Chapter 10 (even if it is over 250 pages long). As in the previous chapter, so in this one, Wright employs "broad brushstroke" exegesis, even to the point of seeking to expound an entire letter all at once (see 976-980). Like the previous chapter, Paul's language is parsed against a particular construal of the story of Israel, such that his theology of the people of God is a reworking of an "essentially Jewish" vision of election. ${ }^{10}$

And that Jewish story, Wright maintains, runs like this: Israel was called to be a blessing to the nations, to undo the sin of Adam and its effects, an Abraham-shaped fact which constitutes their election. But it also failed in this call. In so doing, Israel, because of the Torah, became the focal point for the sin of Adam. So Israel is both God's agent to "put the world to rights" and herself a part of the problem, caught up in sin, particularly idolatry and immorality, which is now vigorously concentrated in Israel by Torah. The people of God thus find themselves waiting for the story to continue, for the eschatological fulfillment of God's covenant promises to Abraham, which was fundamentally about bringing blessing to the gentiles. Paul's reworking of this vision, Wright maintains, is seen in portraying Jesus as the eschatological continuation of God's covenant purposes, now centred on her Messiah as he is the one who sums up Israel in himself. And unlike faithless Israel, which caused a problem

8. See Bauckham, R. J. (2008). Jesus and the God of Israel. Milton Keynes: Paternoster.

9. Wright, N.T. (1996). Jesus and the Victory of God. London: SPCK, pp.612-653.

10. It is only a slight exaggeration to say that the phrase "essentially Jewish" and such like pepper almost every page of $P F G$. 
inherent in God's own righteousness - to be both faithful to his covenant to bring blessing and impartial in judging faithless Israel (see, e.g., 933)-Jesus as Messiah is now the faithful Israelite, solving the problem. Because of this, Paul can speak of Jesus as the one through whom God reconciled the world to himself.

This sets the stage for understanding Paul's "justification" language and the following crucial point: the apostle's "justification" language plays a part-but only a part-in this "Pauline reimagining" of what he often calls an "essentially Jewish" story, a rethinking that happens around Jesus the Messiah. To elucidate this, Wright develops his understanding of "justification" in seven sections. What is more, he constructs his argument in such a way as to bring together interpretations of Paul that are often at odds with one another. So he speaks of the "anthropological", "forensic", "apocalyptic", "covenantal" etc. aspects of this reimagined Jewish eschatological hope. Ultimately, by focusing particularly on covenantal themes, and the narrative connection with Israel and her hopes, Wright aims to present a picture of Paul that is coherent and can give different interpretive paradigms a place in a larger picture. The result is that justification becomes a very particular speech-event which cuts into a variety of concerns. It is a pronouncement in the present over all who are incorporated "in the Messiah". It is the forensic verdict made on the basis of the death of Jesus that "this really is my adopted child, a member of Abraham's covenant family, whose sins are forgiven" (958-959, italics suppressed), it marks out those in the present who will be vindicated at the great Assize. Legal, covenantal, anthropological, apocalytpic and "salvation history" concerns all find their place in this portrayal. Unlike Wright's earlier and less guarded formulations, ${ }^{11}$ soteriology is certainly not collapsed into ecclesiology, but is part of a complex web of concerns all detailed in these seven sections.

In a way which circles back to his proposals in the previous, ninth, chapter, Wright notes that the faith which justifies is also that which says "Jesus is Lord". In other words, his portrayal of Paul's christological and pneumatological revision of Jewish monotheism "dovetails" nicely with the thesis of Chapter $10 .{ }^{12}$ This leads us to note one of the main claims pursued in PFG, and one of the work's most original contributions. Namely, theology is, for Paul, the central task in supporting his newly reimagined worldview. With the symbol of Paul's mindset now leaning on the "church", justification in particular supports this wider worldview, making clear who now belongs to God's "covenant people". This is the reason why Paul begins, out of necessity, the task of Christian theology; it was necessary for the maintenance of the worldview he wished to undergird and support.

Remembering that Wright asserts there are three main elements of Jewish theology (monotheism, election and eschatology), the final section of Part III concerns Wright's account of Paul's reimagining of Jewish eschatology. Once again, Wright sees Paul reimagining very Jewish hopes and expectations about the future of the world around Jesus

11. See Wright, T. (1997). What Saint Paul Really Said. Oxford: Lion, p.119.

12. Wright likes the word "dovetail". He uses it, according to my count, almost twenty times in PFG. 
and the spirit, something also driven by Wright's account of Paul's redefinition of Jewish views of election, pursued in the previous chapter. All of this involves an extensive and close analysis of particularly Romans 9-11. The sum result is that by analysing Paul's reworking of Jewish monotheism, election and eschatology, Wright is confident that his "sketch of Paul's theology is complete" (1258).

The final section of $P F G$, Part IV, explores the way in which Paul's theology confronts Caesar's empire (chapter 12), ${ }^{13}$ the wider "religious" world (chapter 13) and philosophical schools, particularly the Stoics (chapter 14). ${ }^{14}$ In chapter 15, Paul's relationship with his own Jewish context is further elaborated, and here Wright engages with the debate relating to whether we should speak of Paul's conversion, call or transformation, the thorny issues of Jewish "identity", and Paul's use of Israel's Scriptures. ${ }^{15}$

The 16th and final chapter recapitulates many of Wright's claims to have successfully brought together theology and exegesis, as well as the various vying schools of Pauline interpretation, into a more pleasing and healthy whole. In particular, this final chapter involves some robust rhetoric against "apocalyptic" readings, and suggests a project of reconciliation, which is indeed one of the key aims of Paul's ministry (1496).

In closing this summary, it need only be added that this is, of course, an extremely (and necessarily) selective and short summary of a massive project. To grasp the depths and richness of Wright's arguments and to understand the interconnections and mutually reinforcing nature of many of his eloquent proposals, it would be necessary to work through all 1600 pages. That is a lot to read, but it is a task made easier by the fluidity and beauty of Wright's writing.

\section{A critical assessment}

The posture I take in the critical part of this review is that of a relatively junior scholar assessing the work of a far more senior academic, one who is an internationally major player in not only Pauline studies, but also the entire sweep of early Christianity. I say this, as I will spend quite a deal of space in the rest of this review being critical of Wright's project. But I do this not because I think PFG is especially deserving of sharp criticism-far from it-, but because Wright's book is so important that it demands such critical reflection. Hence, I would ask Tom-and indeed any Tomists-for his correction, where I have misunderstood or misrepresented him, or otherwise made unfair or faulty objections.

\section{Positives}

13. This chapter involves a particularly good dialogue with John Barclay.

14. This involves rather lively engagement with the scholarship of Troels Engberg-Pedersen.

15. This latter issue involves good discussion with the scholarship of Francis Watson. 
PFG is unquestionably a major publishing event, and any who would simply dismiss this monumental monograph, or pretend it does not exist, ought not be taken seriously by the rest of the scholarly community. Among the many other things that could be said in praise, I would note the following. His exegetical method was most refreshing. Instead of getting hung up on isolated verses, Wright is never in danger of losing the wood for the trees. He boldly engages whole swathes of material, and does not allow his argument to get lost in footnotes. Likewise, his proposal about Paul as the originator of Christian theology is indeed one worth pondering, as is his concern to develop a "thick" description of the apostle Paul. As I will note below, I am not persuaded that he sufficiently grasps Paul's historical contingency and particularity, but this "thick" description goes some way to honouring these concerns. Perhaps most impressively is Wright's ability to tackle lots of questions all at once. In so doing, he includes a vast sweep of material in his own developing proposals. He presents a portrait of Paul that respects the sweep of the Christian canon in ways others have not. He clearly sees the many problems that confront Pauline studies and that need to be addressed (e.g., 1515), and he brilliantly brings all of this into dialogue with "ethical" and "political" questions (see, e.g., 43).

So many details could be added to this list of positives, such as Wright's discussion with Barclay in chapter 12, which was a model of careful and respectful engagement (even if I remain largely persuaded by Barclay). His comments about Jewish monotheism at the beginning of Part III demonstrated tremendous insight, as did his helpful rebuttal of the tendency to claim that "paganism is inclusive" (250). Chapters 3-5 provided an excellent introduction to many traditional "background" issues that would be necessary to cover in any introduction to the New Testament. Simply put, this work's intelligent and helpful structure, and transparent argumentation, leave other Pauline theologies in the dust. What is more, the task of reading a massive book like this was also lightened by Wright's occasional humour. My personal favourite is found on page 944 when discussing "inaugurated-eschatological forensic-covenantal incorporation". He wryly adds that perhaps this would have been easier to state in German: Allerdings!

\section{Negatives $^{16}$}

16. A few other issues could be pursued, but given space limitations, I will simply note my main objections. However, it would be desirable to have elaborated upon the following concerns, some of which have wider ramifications:

(a) I am not convinced that the claim "Messiah-people should learn to see the glory of the Lord in one another" (441) accurately represents good exegesis of 2 Cor. 3:18 (on this, see Rabens, V. (20132). The Holy Spirit and Ethics in Paul: Transformation and Empowering for Religious-Ethical Life, WUNT II/283. Tübingen: Mohr Siebeck, p.178 n.25).

(b) The claim that "[no]body contradicted him" (157) is problematic. It is an argument from silence.

(c) Wright's repertoire of illustrations were decidedly "high culture" (Shakespeare [473], Mozart [1018], JS Bach [1484] etc.), which can strike one (of my own cultural situatedness, at least) as a little pretentious.

(d) His claim that pistis is not christological but nevertheless hypostatized is very strange (873), especially given the relationship between Christ and pistis in Gal. 3, which strongly suggests it is christological.

(e) He argues that in writing "Those who do the law will be justified", "Paul means exactly what he says" (937). But quite apart from the idea that the text is self-interpreting, the claims appears to be false even for 


\section{Critical issue 1: Length.}

The first thing that needs to be said is that PFG is too long. Wright needed a stronger editor to push back on the slightly verbose illustrations and repetitive nature of many of his arguments. For example, he (I think wrongly) states perhaps dozens of times that the "apocalyptic" reading of Paul is anti-Jewish, un-Jewish, or some similar variation, or that this or that is Paul being "essentially Jewish" etc. When the word "concise" has nightmares, it's dreaming of $P F G$.

\section{Critical issue 2: The "controlling story".}

Second, problems associated with Wright's construal of his "controlling story" should be noted. On the one hand, it is almost inevitably reductionist, oversimplifying what is arguably a far more variegated reality. For example, there are problems with Wright's position concerning Paul's pre-Christian Pharisaic life. And let it be remembered that this is, for Wright, the necessary background against which "we must imagine all [Paul's] rethinking and reworking of prayer, thought and life to have taken place" (86). His claim, despite Acts which speaks of Paul as a student of the Hillelite Gamaliel (Acts 22:3), is that "Paul had almost certainly been on the Shammaite side" (86). Wright's construct of this pre-Christian Paul is based on use of evidence for "Pharisees" that "don't declare themselves to be Pharisaic (e.g., Psalms of Solomon)". ${ }^{17}$ Wright's claims involve a dated approach to constructing what "Pharisaic" meant, and is not endorsed by modern specialists. ${ }^{18}$

One must also question whether Wright's construction of Paul's Jewish world suitably honours key sources such as the Similitudes of Enoch and Philo. The latter is an author whom Wright marginalises at key points (627 n. 33; 1315) despite the fact that Philo, in terms of literary output, ranks as the most important source for understanding the $1^{\text {st }}$ century Jewish world, alongside Josephus. ${ }^{19}$

Other aspects of Wright's narrative, which becomes controlling for his reading of Paul, could also be challenged, particularly his understanding of the missional impulse of the "Jewish story" for the nations. Wright bases much on his reading of the language of "blessing" in Genesis 12:3, but Walter Mobley has argued that these claims betray a Christian influence, and that an idiomatic meaning of "blessing" is to be preferred. ${ }^{20}$ Further, the relationship between God, Israel and the nations is arguably not reducible to Wright's vision without

\footnotetext{
Wright, as he thinks it doesn't precisely mean what it says, but only what it is reread in light of later chapters, as he goes on to explain (939-940).

17. See Mason, S. "Response to N.T. Wright," SJT (forthcoming 2015).

18. See Mason, S. "Response to N.T. Wright," SJT (forthcoming 2015), where he notes: "Justifications offered for declaring texts Pharisaic when they do not mention the Pharisees have since been discredited as arbitrary and uncontrollable (Rivkin, Neusner, Mason)". See also Mason, S. (1991). Flavius Josephus on the Pharisees: $A$ Composition-Critical Study. Leiden: Brill.

19. He also unconvincingly explains away the importance of philosophical discourse for Josephus (181).

20. Moberly, W. (2009). The Theology of the Book of Genesis. Cambridge: Cambridge University Press, pp.141-61.
} 
considerable reductionism. One need only contrast Ezra 9-10 with Ruth, or the plethora of positions in the Hebrew Bible that OT scholars seek to understand in terms of debate or argument. ${ }^{21}$ So Walter Brueggemann writes of Israel's relation to the nations by noting the following: "The tension between 'through Israel' and 'independent of Israel', as we shall see, is a complicated matter, and one that admitted of no obvious or simple articulation". ${ }^{22}$ Nevertheless, the New Testament scholar, Wright, is confident that "YHWH's choice of Israel as his people, was aimed not simply at Israel itself, but at the wider and larger purposes which this God intended to fulfil through Israel" (804).

Likewise, for Wright, being "in God's image" is about "reflecting God into the world" (487. See also 493). The boast of Jews is, for Wright, that "Israel as a whole is charged with putting the world to rights" (812). But again, all of this sounds like a selective and retrospective Christian reading of aspects of OT stories, not something self-evident to second-temple Jews. When Wright anticipates this argument, on pages $805-807$, he fails to meet the objection and instead sidetracks into a discussion about supersessionism. But this means that he does not address the question of real substance. ${ }^{23}$ Hence, I am not persuaded that Wright has countered the objection that his construal of key aspects of the story of Israel isn't something self-evident to second-temple Jews prior to a particularly Christian articulation. It is not a "given" that Paul then had to remold. Rather, the relationship between Paul's Christian rereading, and the prior narrative, is, I would suggest, a little more complex.

But Wright's elaborate and often brilliant construct becomes the key for structuring his analysis of Paul; it is determinative for his results when reading Paul's letters. Hence, and likewise, crucial to Wright's understanding of Paul's Christology of "divine identity" is that Jesus is the embodiment of the return of YHWH to Zion. Indeed, by reading Paul's letters in this light, he claims that it is the missing key that unites everything else. But did Jews, who faithfully offered sacrifices in the temple, really think that YHWH was absent? I find this difficult to believe, and Wright's account seems to be more about hermeneutics than lived realities. Or again, absolutely crucial is Wright's claim that Jewish theology can be structured around three themes, namely monotheism, election and eschatology. But he does not demonstrate this as much as assert it. It is not, then, unreasonable to question whether the actual evidence is not the snug fit he suggests. So Mason notes that Josephus, a key Jewish author from the 1st century, discusses monotheism a little, but not election or

\footnotetext{
21. See Stark, T. (2011). The Human Faces of God: What Scripture Reveals When It Gets God Wrong (and Why Inerrancy Tries to Hide It). Eugene, OR: Wipf \& Stock; Brueggemann, W. (1998). Theology of the Old Testament: Testimony, Dispute, Advocacy. Minneapolis: Fortress.

22. Brueggemann, W. Theology of the Old Testament, p.492.

23. Similarly, I find his regular claim that critics of salvation-history have missed the point because it is more a "damnation history" than smooth salvation (e.g., 118, 780) is itself missing the point of the epistemological concerns found in scholars such as Martyn and Campbell.
} 
eschatology, ${ }^{24}$ and if Josephus isn't doing what Wright says second-temple Jews did, how seriously can we take these (determinative) constructs for reading Paul?

For Wright it is "Paul's native Jewish world" that sets the theological agenda, and especially, of course, this when parsed in Wright's terms. ${ }^{25}$ But (a) this is a controversial (and arguably reductionist) construct, (b) I would prefer that Paul's letters set the theological agenda, and (c) one must ask whether Christ is dominant and determinative enough in Wright's interpretative scheme, laid out in his 7th chapter. Although this chapter is very helpful, Christ is, Wright argues, a subplot within another story. But does this recognise the priority of Christ in Paul, as knowledge of the risen Lord, and devotion to him, is the warp and woof, the life-blood, of the apostle's life and letters in a variety of ways, as well as Paul's "epistemological key" (2 Cor. 5:16-17). ${ }^{26}$ If Wright is correct about Paul's Christology of "divine identity", as I believe he is, then Christ is in some mysterious yet ontological way, God. In this case, creation is for Christ (Col. 1:18) and this means that fitting Christ into a Pauline narrative subplot-a smaller story within a larger one-could lead us away from the heart of Paul, however well this is nuanced. And if Christ is a sub-plot, concerns arise that, despite Wright's denials, Christ is a Plan B, which is likely to cause theological as well as exegetical trouble. ${ }^{27}$

Wright's worldview analysis, of which the matter of "controlling story" is a part, raises another outstanding concern. On the one hand, Wright regularly notes that a worldview is not something that you look at but rather through. However, Wright also suggests that Paul "advocates" and "commends" "a worldview" $(36,263)$. So Paul commends what is not looked at? This seems odd, ${ }^{28}$ as does his claim that there is one early Christian worldview ("the early Christian worldview", 456 italics mine), which sounds reductionist.

We have seen that Wright wants to speak about "a complex but essentially single narrative" (77. See also 114, 116-117 etc.) into which he will fit Paul. But his account is perhaps too "neat" and does not allow the reality of the "messiness" of these Jewish texts to stand. Of course, Wright is well aware that his construct is a hypothesis, and he indeed advocates the need to test and adjust that proposal in light of the actual evidence, particularly Paul's

24. Mason, S. "Response to N.T. Wright," SJT (forthcoming 2015).

25. Wright seeks to allow "Paul's native Jewish world to set the theological agenda" (46).

26. See, e.g., Rom 1:5; 12:11; 14:6-9; 16:5; 1 Cor $1: 7 ; 1: 31 ; 2: 2 ; 6: 13,16-17 ; 7: 25-38 ; 11: 23-26 ; 12: 3 ; 15: 19$,

58; 16:22; 2 Cor 3:16-18; 4:5, 8, 10-11; 5:9-10, 15; 8:5, 19; 10:7; 10:17; 11:2-3; 12:7-10; Gal 2:20; 3:29; Phil 1:20, $23 ; 2: 6-11 ; 3: 1,8 ; 4: 4,10 ; 1$ Thess $1: 2-3 ; 3: 8,11-13 ; 4: 17 ; 5: 10,17$; Philm 6.

27. On Wright's potential infralapsarianism, see now van Driel, "Climax of the Covenant Vs Apocalyptic Invasion: A Theological Analysis of a Contemporary Debate in Pauline Exegesis," IJST 17(1): 6-25. On the wider point, see Campbell, D. A. (2014) "Paul's Apocalyptic Epistemology: What is at Stake?" Society of Biblical Literature meeting (San Diego).

28. I am reminded of a similar confusion in Gordon Fee when he claimed that Paul is 'speaking presuppositionally about Christ's preexistence' in Galatians (Fee, G. D. (2007). Pauline Christology: An Exegetical-Theological Study. Peabody: Hendrickson, p.215, italics mine). Speaking, like advocating and commending, is an active matter, expressing something concrete, or it is not speech. 
letters (xviii, 55-56, 1359), but in the following few points, I will suggest that he has not entirely succeeded in doing this in practice.

\section{Critical issue 3: Wright's Christology of "divine identity".}

I was very happy with Wright's claim that Paul's Christology is "divine". However, I do not think the phrase "divine identity" solves all interpretative issues. Furthermore, despite the fact that I'm sincerely honoured that he spent time reading my monograph, Wright is not quite correct to locate my own work (Paul's Divine Christology) "within" Larry Hurtado's interpretative trajectory (651). My own proposals correspond more closely to Richard Bauckham's.

I have already registered my concern about superimposing the theme of the "return of YHWH to Zion" onto Paul's letters. More to the point, Wright considers his proposal to be the way to get "to the heart of what Paul" believed about Jesus (633), and that when we recognise this story it integrates data previously left out of the equation (653). It is fair to suggest that Wright may have identified certain plausible intertextual allusions, in at least a couple of passages, with the return of God to Zion, especially when temple-themes are present. But this does not show why Paul unites themes such as love for Christ and other expressions of intense devotion, and how this corresponds with Christ's absence, the related language of Christ-related aims, as well as the descriptions of Christ's character etc., in the way he does.

Nor does it respect the fact that Paul expresses all of this in terms that only sometimes correspond to Wright's scriptural themes of new Exodus, return to Zion etc. I cite as examples of such christologically pregnant Pauline language (which often reflect scriptural themes unrelated to Wright's emphases), verses in Romans and 1 Corinthians. I do so not because these letters are especially pertinent to my point (as much as, say, 2 Cor. and Phil.), but because they were the first I scanned, and the list would have become unwieldy by adding data from Paul's other letters. So, see Rom. 8:35, 39; 14:7-9, 18; 15:7, 11, 29; 16:18, 20; 1 Cor. $1: 2-3$, 7; 2:2, 8; 3:5, 11; 4:4-5, 10; 4:19; 5:5; 6:13, 17; 7:17, 22, 32-35; 8:6, 12; $10: 21 ; 12: 3-7 ; 15: 58 ; 16: 22-23$.

It follows that Wright's proposal is not sufficiently key to the scope of Paul's actual christological language to justify his claim about its purported interpretative centrality. ${ }^{29}$ This is all to say that Paul's letters are simply not sufficiently explained by Wright's reading strategy. I would argue, then, that Wright makes his "this gets to the heart of Paul" claim, not due to Paul's letters but rather because of his front-loading of interpretative layers. These are then imposed, with greater and lesser success, onto the Pauline data itself (witness the interpretative method on this point in 633, for example).

29. Compare the extent of language in Paul discussed in Tilling, C. (2012). Paul's Divine Christology, WUNT II Tübingen: Mohr Siebeck, pp.75-195. 
Apart from what is missed, I note that, in his exegetical claims, Wright is prone to say this or that verse is "key", a "bookend" (834-835), a "rhetorical climax", and such like. But I suggest that this is done rather arbitrarily, and sometimes only when it suits him. For example, he claims that 1 Cor. 8:6 is the "dense opening Christological statement" for the wider argument of 1 Cor. 8-10 (661), and that 8:5-6 are the "rhetorical climax" of the passage (664). But this is exegetically problematic. 8:1-3 explicitly set the agenda for the following arguments, and Wright doesn't suitably account for this. ${ }^{30}$ In other words, I'm not persuaded that Wright had successfully explained the "what" question, namely the nature of Paul's divine Christology. On the positive side, Wright is one of the only scholars to really seriously ask the "why" question, yet his recourse to the "return of YHWH to Zion" story, at this point, perhaps reflects more about his book JVG than Paul's letters.

Editor's note: The review is continued in Part 2. 